\title{
Spring defoliation effects on bluebunch wheatgrass: I. Winter forage quality
}

\author{
PATRICK E. CLARK, WILLIAM C. KRUEGER, LARRY D. BRYANT, AND DAVID R. THOMAS
}

\begin{abstract}
Authors are range scientist, USDA Agricultural Research Service, Boise, Ida. 83712; professor, Department of Rangeland Resources, Oregon State University, Corvallis, Ore. 97331; range ecologist, USDA Forest Service, Washington, D.C. 20250; and professor, Department of Statistics, Oregon State University, Corvallis, Ore. 97331. At the time of the research, Clark was graduate research assistant, Department of Rangeland Resources, Oregon State University, Corvallis, Ore. 97331 and Bryant was wildlife biologist, USDA Forest Service, Pacific Northwest Research Station, La Grande, Ore. 97850. Research was funded by USDA Forest Service, Pacific Northwest Research Station, La Grande, Ore. and by Cooperative State Research Service.
\end{abstract}

\begin{abstract}
The winter forage quality of bluebunch wheatgrass (Agropyron spicatum [Pursh] Scribn. \& Smith) is generally inadequate for maintenance of wintering Rocky Mountain elk (Cervus elaphus nelsoni Bailey). Previous attempts to improve the winter forage quality of bluebunch wheatgrass by clipping and livestock grazing have achieved mixed results. We report crude protein (CP), in vitro dry matter digestibility (IVDMD), and dry matter (DM) yield responses of bluebunch wheatgrass to 3 phenological stage/defoliation intensity treatment combinations. The study was conducted in 1993 and 1994 at 2 sites in the Blue Mountains of northeastern Oregon. Bluebunch wheatgrass was hand clipped to a 7.6-cm stubble height in early June under 1 of 3 treatment combinations: 1) mid-boot/whole-plant clipped, 2) mid-boot/onehalf of the plant's basal area clipped, and 3) inflorescence emergence/whole-plant clipped. Early November levels of CP and IVDMD were greater under all 3 treatments compared to an unclipped control. Mean forage quality improvement over the control was greatest in the inflorescence emergence treatment with an improvement of 1.3 percentage points for $C P$ and 5.8 percentage points for IVDMD. Dry matter yield of the control exceeded that of all clipping treatments. Increases in forage quality resulting from forage conditioning treatments may be important to the viability of elk populations wintering on rangelands where forage quality, rather than quantity, is limiting.
\end{abstract}

Key Words: Agropyron spicatum, Cervus elaphus, elk, forage conditioning, nutrition, phenology, winter range, elk

Many Rocky Mountain elk (Cervus elaphus nelsoni Bailey) in northcastern Oregon, as in other western states, winter on what were historically transitional or spring-fall rangelands (Skovlin and Vavra 1979, Sheehy 1987, Sheehy and Vavra 1995, Sheehy and Vavra 1996). Suburban expansion, agricultural development, and other forms of human disturbance have made much of the traditional elk winter range on valley floors and lower elevation foothills unavailable to wintering elk. Consequently, many elk in

Authors wish to thank J. Cook, T. DelCurto, B. Dick, J. Kie, R. Riggs, E Starkey, M. Vavra, and 3 anonymous reviewers for their critical review and comments on drafts of this manuscript.

Manuscript accepted 14 Mar. 1998. northeastem Oregon occupy spatially incomplete winter habitat (Sheehy and Vavra 1995).

The winter forage quality of bluebunch wheatgrass (Agropyron spicatum [Pursh] Scribn. \& Smith) and Idaho fescue (Festuca idahoensis Elmer), which are the dominant forage species on transitional rangelands of northeastern Oregon, is commonly inadequate to meet maintenance requirements of wintering elk (Westenskow 1991, Bryant 1993, Clark 1996). Anderson and Scherzinger (1975) suggested spring livestock grazing may be useful to improve the winter forage quality of perennial grasses such as bluebunch wheatgrass since regrowth produced by grazed plants may cure in a phenologically younger, more nutritious state than ungrazed plants. Many studies have examined the effects of defoliation on forage production and chemical composition of bluebunch wheatgrass (McIlvanie 1942, Stoddart 1946, Blaisdell et al. 1952, Willms et al. 1980b, Daer and Willard 1981, Pitt 1986, Bryant 1993, Westenskow-Wall et al. 1994). Results from these studies suggest the forage quality and quantity response of bluebunch wheatgrass to defoliation is strongly related to phenological timing of defoliation, amount of photosynthetic and meristematic tissue removed, and number of defoliations occurring during the growing season. An effective phenological stage/defoliation intensity treatment combination for use in improving the winter forage quality of bluebunch wheatgrass has not been determined for the environmental conditions of northeastern Oregon.

Our objective was to examine the effect of several, previously uninvestigated phenological stage/defoliation intensity treatment combinations on early winter levels of CP. IVDMD, and DM yield of bluebunch wheatgrass on elk winter range in northeastern Oregon. Forage quality results from each of the treatments and from an unclipped control were compared to estimates of the early winter nutritional requirements of elk.

\section{Materials and Methods}

\section{Study Area}

The study was conducted in 1993 and 1994 at 2 study sites; Winter Ridge and McCarty Spring, located in the Blue Mountains of northeastern Oregon approximately 35 and $48 \mathrm{~km}$ southwest of La Grande, Ore., respectively. Both study sites were located on 
USDA-Forest Service land managed as big game winter range. The following criteria were used in selection of the study sites: (1) location on an open ridgetop, (2) southerly to westerly aspect, (3) grassland vegetation type dominated by bluebunch wheatgrass, (4) sufficient density of vigorous bluebunch wheatgrass plants for statistically rigorous sampling, and (5) representative of winter range frequently used by elk from November to April.

An 0.8-ha livestock exclosure had been constructed at each study site in 1986 (Bryant 1993, Westenskow-Wall et al. 1994). The McCarty Spring exclosure was located on a gently sloping ( 0 to $5 \%$ ) westerly aspect at $1,274 \mathrm{~m}$ in elevation. The elevation of the Winter Ridge exclosure was $1,366 \mathrm{~m}$ with a gently sloping ( 0 to $7 \%$ ) south-southwesterly aspect.

Vegetation at both study sites was classified as bunchgrass on shallow soil, gentle slopes (Hall 1973:GB-49-11). The dominant perennial grasses were bluebunch wheatgrass, Idaho fescue, Sandberg bluegrass (Poa secunda Presl.), prairie junegrass (Koeleria cristata Pers.), and Kentucky bluegrass ( $P$. pratensis L.). Annual grasses such as cheatgrass (Bromus tectorum L.) and soft brome (B. mollis L.) dominated ecologically-disturbed sites. Western yarrow (Achillea millefolium L.) was the most common perennial forb. No shrubs were recorded at either site.

Soils on both sites were shallow, extremely stony to very cobbly, loams and silt-loams of the Anatone-Bocker complex (Dysterhuis and High 1985, Bryant 1993). The shallowness and droughtiness of these soils were likely the most limiting factors to vegetative production (Dysterhuis and High 1985).

The climate was continental with low precipitation, warm to hot summers and cold, dry winters. Most of the precipitation occurred as winter snow and spring rain. The amount and timing of late summer and fall rain was unpredictable but could occur in sufficient amounts to promote substantial regrowth in perennial grasses. Annual precipitation totals for 1993 and 1994 at Starkey Experimental Forest and Range, less than $15 \mathrm{~km}$ away from both study sites, were $56.6 \mathrm{~cm}$ and $54.4 \mathrm{~cm}$, respectively (Fig. 1). The 10 year (1986 to 1995) maximum, minimum, and mean annual precipitation at Starkey Experimental Forest and Range was 36.2, 72.0 , and $54.8 \mathrm{~cm}$, respectively (Unpub. data, on file at Forestry and Range Sciences Laboratory, La Grande, Ore.).

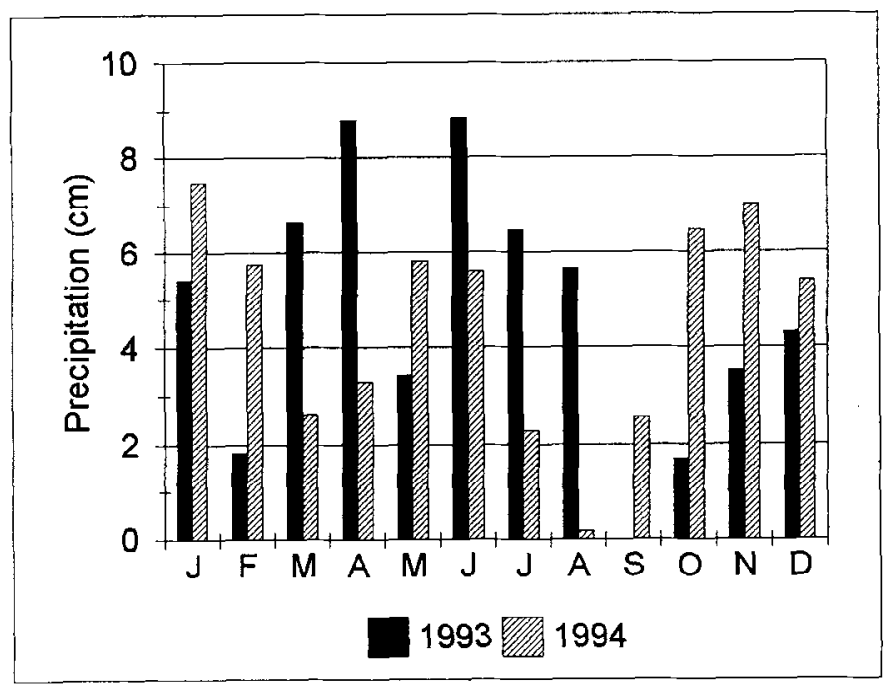

Fig. 1. Monthly precipitation for 1993 and 1994 at Starkey Experimental Forest and Kange near La Grande, Ore.

\section{Experimental Design}

A completely randomized experimental design was used. At each study site, the area within the livestock exclosure (excluding a 10-m wide fence buffer zone) was divided into $10 \mathrm{~m}$ by $10 \mathrm{~m}$ plots resulting in a rectangular block of 44 plots at the McCarty Spring exclosure and a rectangular block of 39 plots at the Winter Ridge exclosure. From the available plots at each study site, 32 plots were randomly assigned to a clipping treatment and year of treatment application.

All bluebunch wheatgrass plants within each randomly chosen plot received 1 of 4 possible treatments: (1) unclipped control, (2) the entire basal area of the plant was hand-clipped to a $7.6-\mathrm{cm}$ stubble height during the mid-boot phenological stage, (3) onehalf the basal area of the plant was hand-clipped to a 7.6-cm stubble height during the mid-boot stage and, (4) the entire basal area of the plant was hand-clipped to a $7.6-\mathrm{cm}$ stubble height during the inflorescence emergence stage. The mid-boot/half-plant clipping treatment was included to simulate the grazing system suggested by Anderson and Scherzinger (1975) for conditioning elk winter range forage (i.e., moderate stocking and short duration). Partial defoliation, as represented by the mid-boot/half-plant treatment, may more accurately simulate moderate grazing than traditional whole-plant clipping. The 7.6-cm stubble height was used because previous research indicated clipping to stubble heights less than 7.6-cm (Stoddart 1946, Blaisdell and Pechanec 1949) may severely impact plant vigor and sharply limit regrowth. Clipping to stubble heights greater than 7.6-cm (Pitt 1986) may not adequately delay the phenology of subsequent regrowth since the apical meristems of bluebunch wheatgrass typically are not removed by this level of defoliation and regrowth occurs by continued elongation and development of existing tillers rather than by production of new tillers from axillary buds.

Each clipping treatment was replicated 4 times at each study site during 1993. The entire experiment was replicated in 16 new plots at each site during 1994.

During early November of 1993 and 1994, forage samples were collected from plots treated during the previous spring. Samples were cullected by randomly locating four, $1 \mathrm{~m}$ by $1 \mathrm{~m}$ quadrats within each treated plot and clipping all the bluebunch wheatgrass plants within the quadrats to a $2.5-\mathrm{cm}$ stubble height. All the material harvested from the 4 quadrats was combined into 1 composite forage sample per plot.

The forage samples were oven-dried at $50^{\circ} \mathrm{C}$ until a constant dry weight ( \pm 0.01 grams) was reached. The dried samples were then ground to pass through a 1-mm mesh screen. Dry matter percentage of each sample was determined by oven-drying 2 subsamples at $100^{\circ} \mathrm{C}$ until a constant weight $( \pm 0.01$ grams) was reached. Dry matter percentage of each sample was used to correct the original sample weight to a $100 \%$ dry matter basis. Crude protein (CP) percentage was determined in duplicate using the kjeldahl method as described by the Association of Official Analytical Chemists (AOAC 1980). In vitro dry matter digestibility (IVDMD) percentage was determined in triplicate (Tilley and Terry 1963). Rumen inoculum used in the digestibility analysis was a composite sample collected from 2 fistulated Hereford steers maintained on meadow hay. Digestible energy (DE) (Schommer 1978) and metabolizable energy (ME) (Smith 1971, Thompson et al. 1973) for elk were calculated from the IVDMD of forage samples using the following equations:

$\mathrm{DE} \mathrm{kcal} \mathrm{g}^{-1} \mathrm{DM}=0.051$ (percent IVDMD)-0.7054 
ME kcal g-1 DM = 0.85(DE kcal g-1 DM)

(2)

Crude protein, IVDMD, and DM were compared between treatments, study sites, and years using analysis of variance procedures (SAS 1988). Where differences were detected, Fisher's Least Significant Difference (LSD) procedure was used to make multiple comparisons of treatment means based on a $5 \%$ level of significance (SAS 1988, Montgomery 1991).

\section{Results}

Treatment $(P<0.01)$, site $(P<0.01)$, year $(P<0.01)$, and site by year $(P<0.01)$ effects were detected for $(C P)$. Crude protein in bluebunch wheatgrass at McCarty Spring was higher than at Winter Ridge (Fig. 2). Forage from 1994 was higher in CP than that from 1993. There was greater variability in the CP response between years at McCarty Spring than at Winter Ridge. This site by year interaction may be due to site factors at McCarty Spring that allowed greater CP response by plants (Fig. 1). Compared across study sites and years, samples from the mid-boot/wholeplant, mid-hoot/half-plant, and the inflorescence emergence clipping treatments were significantly higher $(P<0.05)$ in $C P$ than the unclipped control (Table 1). Crude protein of the mid-boot/wholeplant and inflorescence emergence treatments was similar but both treatments had higher $\mathrm{CP}(\mathrm{P}<0.05)$ than the mid-boot/half-plant treatment. Total CP $\left(\mathrm{kg} \mathrm{ha}^{-1}\right)$ was higher $(P<0.05)$ in the unclipped control than in the other 3 treatments (Table 1). The mid-boot/whole-plant and inflorescence emergence treatments yielded the lowest amount of total $C P(P<0.05)$.

Treatment $(P<0.01)$, site $(P=0.02)$, year $(P<0.01)$, and site by year $(P<0.01)$ effects were also detected for IVDMD. In vitro dry matter digestibility was higher at McCarty Spring than Winter Ridge (Fig. 3). Samples from 1994 had higher IVDMD than those from 1993. The site by year interaction observed may be due to greater responsiveness of plants at McCarty Spring to higher fall precipitation in 1994 (Fig. 1). Compared across study sites and years, samples from the mid-boot/whole-plant and inflorescence emergence treatments had the highest $(P<0.05)$ IVDMD (Table 1). Samples from the mid-boothalf-plant treatment had an intermediate level of IVDMD compared to other treatments. Unclipped control samples had the lowest IVDMD

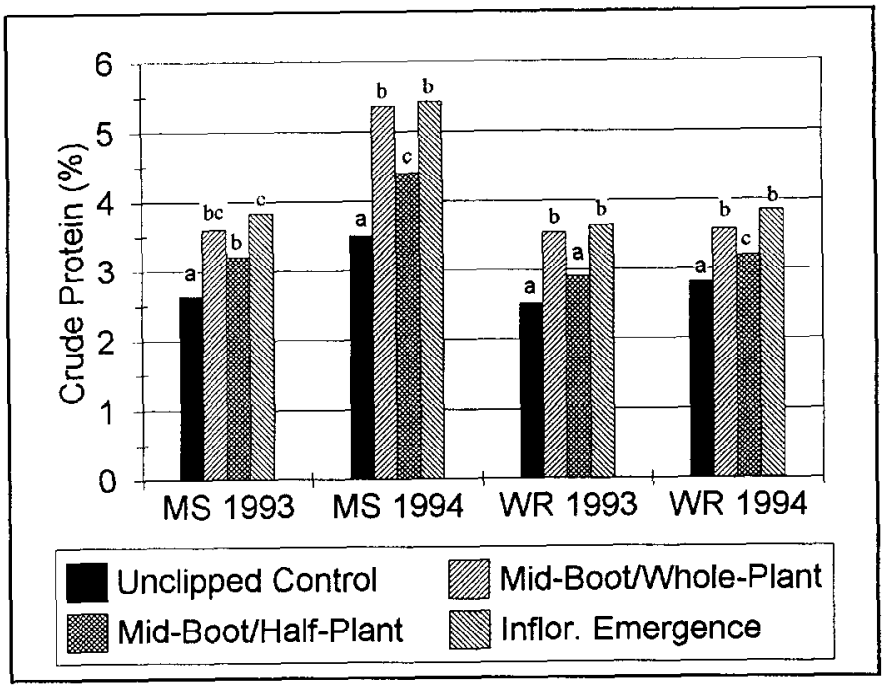

Fig. 2. Early winter levels of crude protein (\%) in bluebunch wheatgrass from each of the 4 treatments. Labels for the $X$-axis correspond to study site/year combinations (e.g., WR $1993=$ Winter Ridge 1993). Bars with different letter codes are significantly different within study site/year combinations $(P<0.05)$.

percentage of the 4 treatments $(P<0.05)$. Mean (DE) digestible energy and mean (ME) metabolizable energy from each treatment are listed in Table 2.

Total IVDMD $\left(\mathrm{kg} \mathrm{ha}^{-1}\right)$ was highest $(P<0.05)$ in the unclipped control (Table 1). The mid-boot/whole-plant and mid-boot/halfplant treatments produced similar levels of total IVDMD. The inflorescence emergence treatment yielded the lowest $(P<0.05)$ total IVDMD of the 4 treatments.

Treatment $(P<0.01)$ and year $(P<0.01)$ effects were detected for (DM) dry matter yield. When analyzed across study sites and years, the DM yield of the unclipped control was higher $(\mathrm{P}<$ 0.05 ) than any of the other 3 treatments (Table 1). Dry matter yield from the mid-boot/whole-plant and mid-boot/half-plant treatments was similar, but both these treatments were higher ( $P$ $<0.05$ ) in DM yield than the inflorescence emergence treatment. Dry matter yield of bluebunch wheatgrass was higher in 1994 than in 1993 (Fig. 4).

Table 1. Forage nutritional value from each of the 4 treatments. Means were calculated across study sites and years.

\begin{tabular}{|c|c|c|c|c|c|}
\hline \multirow[b]{2}{*}{$\begin{array}{l}\text { Nutritional } \\
\text { Value }\end{array}$} & \multicolumn{4}{|c|}{ Clipping treatments } & \multirow[b]{2}{*}{$\begin{array}{l}\text { Std. Error } \\
\text { of Mean }\end{array}$} \\
\hline & Control & $\begin{array}{l}\text { Mid-boot } \\
\text { Whole-plant }\end{array}$ & $\begin{array}{l}\text { Mid-boot } \\
\text { Half-Plant }\end{array}$ & $\begin{array}{l}\text { Inflorescence } \\
\text { Emergence }\end{array}$ & \\
\hline Crude Protein (\%) & $2.9^{\mathrm{a}}$ & $4.0^{b}$ & $3.4^{\mathrm{c}}$ & $4.2^{\mathrm{b}}$ & $\begin{array}{r}0.087 \\
(3)^{1}\end{array}$ \\
\hline Digestibility (\%) & $38.7^{\mathfrak{a}}$ & $44.4^{\mathrm{b}}$ & $41.6^{\mathrm{C}}$ & $44.5^{\mathrm{b}}$ & $\begin{array}{c}0.635 \\
(3)\end{array}$ \\
\hline Dry Matter $\left(\mathrm{kg} \mathrm{ha}^{-1}\right)$ & $499.0^{\mathrm{a}}$ & $251.6^{b}$ & $295.2^{b}$ & $182.7^{\mathrm{c}}$ & $\begin{array}{r}23.58 \\
(3)\end{array}$ \\
\hline Total CP $\left(\mathrm{kg} \mathrm{ha}^{-1}\right)$ & $14.5^{\mathrm{a}}$ & $9.9^{b c}$ & $10.0^{\mathrm{b}}$ & $8.0^{c}$ & $\begin{array}{c}0.738 \\
\text { (3) }\end{array}$ \\
\hline Total IVDMD $\left(\mathrm{kg} \mathrm{ha}^{-1}\right)$ & $194.5^{\mathrm{a}}$ & $111.4^{\mathrm{b}}$ & $123.4^{b}$ & $85.3^{\mathrm{c}}$ & $\begin{array}{c}9.279 \\
(3)\end{array}$ \\
\hline
\end{tabular}

abcMeans followed by different letter codes are significantly different within rows $(\mathrm{P}<0.05)$.

${ }^{1}$ Degrees of freedom used in calculation of standard error of mean. 
Table 2. Daily forage intake (kg DM day ${ }^{-1}$ ) required to meet the metabolizable energy (ME) requirements of a $200-\mathrm{kg}^{\mathrm{elk}}$ on a $100 \%$ diet of bluebunch wheatgrass from each of the late spring clipping treatments.

\begin{tabular}{lccccc}
\hline $\begin{array}{l}\text { Late Spring } \\
\begin{array}{l}\text { Clipping } \\
\text { Treatments }\end{array}\end{array}$ & $\begin{array}{c}\text { In Vitro } \\
\text { Dry Matter } \\
\text { Digestibility }\end{array}$ & $\begin{array}{c}\text { Digestible } \\
\text { Energy }\end{array}$ & $\begin{array}{c}\text { Metabolizable } \\
\text { Energy }^{2}\end{array}$ & $\begin{array}{c}\text { Daily } \\
\text { Forage Intake } \\
\text { Required }^{3}\end{array}$ & $\begin{array}{c}\text { Percent of Maximum } \\
\text { Daily Forage Intake }^{4}\end{array}$ \\
\hline Control & $--(\%) \cdots$ & $--\left(\mathrm{kcal} \mathrm{g}^{-1} \mathrm{DM}\right)--$ & $--\left(\mathrm{kcal} \mathrm{g}^{-1} \mathrm{DM}\right)-\cdots$ & $--\left(\mathrm{kcal} \mathrm{g}^{-1} \mathrm{DM}\right) \cdots$ & $-\cdots(\%) \cdots$ \\
Mid-boot & 38.7 & 1.27 & 1.08 & 8.5 & 170 \\
Mid-boot Half & 44.4 & 1.56 & 1.32 & 6.9 & 139 \\
Inf. Emergence & 41.6 & 1.42 & 1.21 & 7.6 & 152 \\
\hline
\end{tabular}

${ }_{1}$ Based on Schommer (1978) equation for conversion of IVDMD to DE.

${ }^{2}$ Assuming ME is $85 \%$ of DE (Smith 1971, Thompson et al. 1973).

${ }^{3}$ Daily forage intake required to obtain ME requirement of $9,185 \mathrm{kcal}$ (Hobbs et al. 1982).

${ }^{4}$ Based on a $5 \mathrm{~kg}$ /day maximum forage DM intake rate for a $200-\mathrm{kg}$ elk (2.5\% of body weight) (Hobbs et al. 1982).

\section{Discussion}

\section{Phenological Timing of Forage Conditioning}

The boot stage may be the only phenological stage when livestock grazing can be successfully applied to improve winter forage quality of bluebunch wheatgrass without critically impacting plant resource viability. Early-season defoliation generally has less negative effects on plant vigor than defoliation applied later in the growing season (Stoddart 1946, Blaisdell and Pechanec 1949, McLean and Wikeem 1985). However, spring defoliation prior to the boot stage probably will not improve the winter forage quality of bluebunch wheatgrass. In early spring, the apical meristems of bluebunch wheatgrass have not yet been elevated by internode elongation and are not within reach of large grazing animals. Regrowth following early spring grazing occurs by continued elongation and development of existing tillers with little effect on timing of phenological development or forage quality relative to ungrazed plants (Stoddart 1946). Late spring grazing, just prior to the boot stage of bluebunch wheatgrass when internodes are elongating, does delay the phenological development of grazed plants by removing foliage and apical meristems and stim-

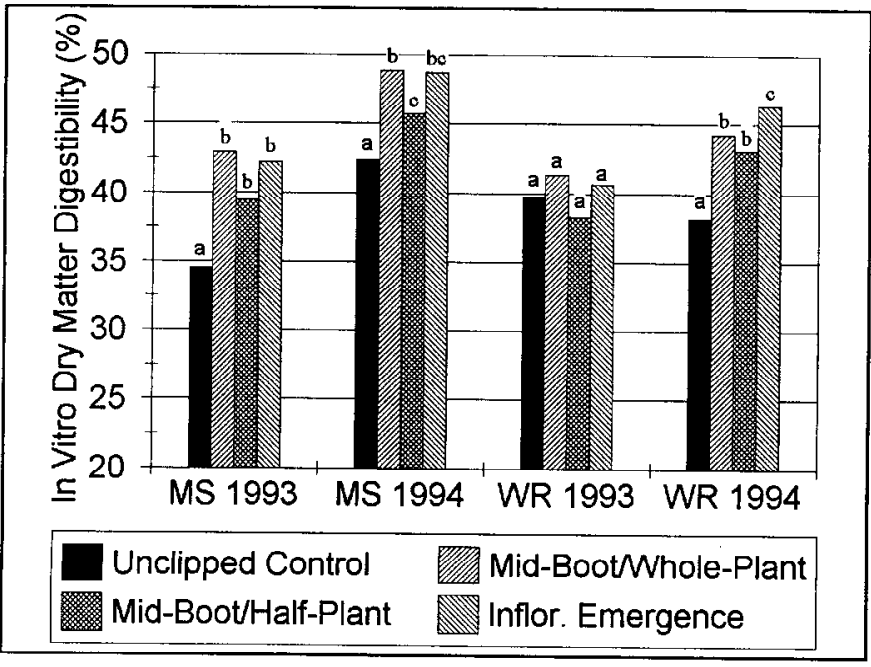

Fig. 3. Early winter levels of in vitro dry matter digestibility $(\%)$ in bluebunch wheatgrass from each of the 4 treatments. Labels for the $\mathrm{X}$-axis correspond to study site/year combinations (e.g., WR $1993=$ Winter Ridge 1993). Bars with different letter codes are significantly different within study site/year combinations $(\mathbf{P}<0.05)$. ulating regrowth from axillary buds. However, under environmental conditions similar to those of northeastern Oregon, a sufficient amount of favorable growing season may remain after preboot grazing to allow axillary tillers on grazed plants to phenologically mature and cure with a chemical composition similar to that of ungrazed plants (Westenskow-Wall et al. 1994).

Defoliation after the boot stage can improve the winter forage quality of bluebunch wheatgrass if regrowth is produced. However, pust-boot grazing, when favorable growing conditions are rapidly declining, can substantially reduce the ability of bluebunch wheatgrass to replace photosynthetic tissue (Busso et al. 1989, Busso and Richards 1995) and forage dry matter (Table 1; Bryant 1993, Busso and Richards 1995) relative to undefoliated plants or plants defoliated prior to or during the boot stage.

Research regarding defoliation of bluebunch wheatgrass during the boot stage reveals an apparent dilemma. While boot-stage clipping delays plant phenology and improves winter forage quality (Table 1), this stage is considered the most injurious time to defoliate bluebunch wheatgrass (Wilson et al. 1966). Declines in basal area of bluebunch wheatgrass following boot-stage clipping are reported in a companion paper to the present report (Clark et

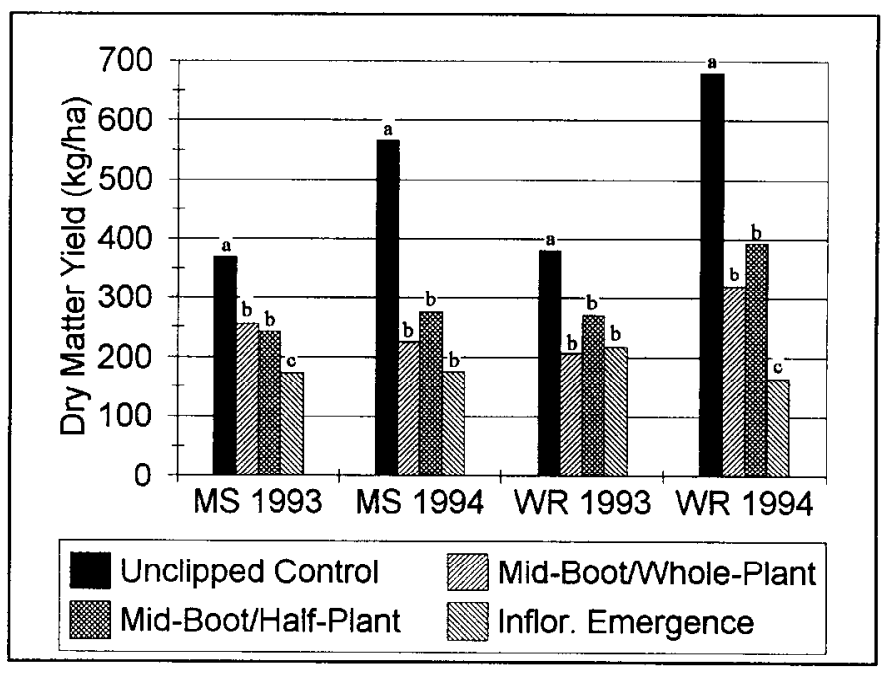

Fig. 4. Early winter levels of dry matter yield (kg ha-1) in bluebunch wheatgrass from each of the 4 treatments. Labels for the $X$-axis correspond to study site/year combinations (e.g., WR $1993=$ Winter Ridge 1993). Bars with different letter codes are significantly different within study site/year combinations $(P<0.05)$. 
Table 3. Daily forage intake (kg DM day ${ }^{-1}$ ) required to meet the nitrogen (N) requirements of a $200-\mathrm{kg}$ elk on a $100 \%$ diet of bluebunch wheatgrass from each of the late spring clipping treatments.

\begin{tabular}{lcccc}
\hline $\begin{array}{l}\text { Late Spring } \\
\begin{array}{c}\text { Clipping } \\
\text { Treatments }\end{array}\end{array}$ & $\begin{array}{c}\text { Crude } \\
\text { Protein }\end{array}$ & $\begin{array}{c}\text { Daily } \\
\text { Digestible } \\
\text { Nitrogen }^{1}\end{array}$ & $\begin{array}{c}\text { Forage Intake } \\
\text { Required }^{2}\end{array}$ & $\begin{array}{c}\text { Percent of Maximum } \\
\text { Forage Intake }^{3}\end{array}$ \\
\hline Control & $-(\%)-\left(\mathrm{g} \mathrm{N} \mathrm{kg}^{-1} \mathrm{DM}\right)$ & (kg DM day- $\left.^{-1}\right)$ & $--(\%)--$ \\
Mid-boot & 2.9 & 4.2 & 8.6 & 172 \\
Mid-boot Half & 3.0 & 5.8 & 6.3 & 125 \\
Inf. Emergence & 4.2 & 4.9 & 7.4 & 147 \\
\end{tabular}

1 Assumed to be $90 \%$ of total $N$ content of the forage (Robbins 1973).

${ }^{2}$ Daily forage intake required to obtain $\mathrm{N}$ requirement of $36 \mathrm{~g} \mathrm{~N}$ day-1 (Hobbs et al. 1982).

${ }^{3}$ Based on a $5 \mathrm{~kg} /$ day maximum forage DM intake rate for a $200-\mathrm{kg}$ elk ( $2.5 \%$ of body

al. 1998). Boot-stage clipping may result in reduced dry matter yield (Table 1) and reproductive culm production (Blaisdell and Pechanec 1949). High mortality rates occur when bluebunch wheatgrass is repeatedly clipped in late spring (Stoddart 1946, McLean and Wikeem 1985). Still, current research suggests a single defoliation during the boot stage may produce some decline in plant vigor, but would not cause substantial mortality of bluebunch wheatgrass provided the plants were not pre-stressed by drought or previous defoliation (Clark et al. 1998).

Is some reduction in plant vigor acceptable in return for improvement in winter forage quality of bluebunch wheatgrass? Certainly, the viability of the plant resource should be the primary concern here. Consequently, grazing-induced declines in vigor may be acceptable only if these declines are temporary and do not jeopardize the competitive status of bluebunch wheatgrass within rangeland plant communities. To improve winter forage quality of bluebunch wheatgrass without compromising its competitive status, a livestock grazing management system must be designed to: 1) obtain a single defoliation of bluebunch wheatgrass plants during the boot stage, 2) minimize regrazing of individual plants during the growing season, and 3 ) rest grazed plants until losses in vigor are fully recovered.

\section{Potential Improvements in Diet Quality}

Although the mid-boot and inflorescence emergence clipping treatments in this study produced considerable improvement in forage quality of bluebunch wheatgrass, results reported above may underestimate actual elk diet quality. Forage samples analyzed in this study included stubble $(5 \mathrm{~cm})$ left from the clipping treatment, standing litter, and regrowth produced following clipping treatments. Elk probably would selectively graze the regrowth rather than the stubble and standing litter in each plant (Jourdonnais and Bedunah 1990), consequently, forage samples collected in this study may have contained more weathered and coarse material than would incidentally occur in actual elk diets.

Reliable estimates of nutritional requirements are needed to assess the influence of diet quality on body condition and performance of free-ranging elk. Many studies have contributed to our knowledge of diet composition and diet quality of elk (see Nelson and Leege 1982), however, published information on nutritional requirements of free-ranging elk is limited. Several researchers have used existing knowledge of ruminant digestive physiology and metabolism, daily activity patterns of free-ranging elk, and nutritional requirements of ruminant livestock to predict the ener- gy and nitrogen $(\mathrm{N})$ requirements of free-ranging elk (e.g., Hobbs et al. 1982, Nelson and Leege 1982, Swift 1983).

Hobbs et al. (1982) estimated a $200-\mathrm{kg}$ elk required $9,185 \mathrm{kcal}$ of (ME) metabolizable energy per day for maintenance and activity during winter. This is probably a reasonable estimate of the total ME requirements of a cow elk in early November, when additional ME requirements for gestation (Nelson and Leege 1982) and thermoregulation (Moen 1973, Swift et al. 1981, Nelson and Leege 1982, Parker and Robbins 1985) are meager.

Based on data from Hungerford (1952), Geis (1954), Hobbs (1979), and Mould and Robbins (1981), Hobbs et al. (1982) estimated the maintenance requirement of true digestible $\mathrm{N}$ for a 200 $\mathrm{kg}$ elk during winter was $7.3 \mathrm{~g} \mathrm{~N} \mathrm{~kg}^{-1} \mathrm{DM}$ assuming a forage intake rate of $5 \mathrm{~kg} \mathrm{DM}_{\text {day }}{ }^{-1}$. Assuming true digestible $\mathrm{N}$ is $90 \%$ of total $\mathrm{N}$ content in a forage (Robbins 1973), this elk would have to consume forages averaging at least $5.1 \% \mathrm{CP}$ to meet its $\mathrm{N}$ requirement. Hobbs et al. (1982) suggested elk consuming forages of less than $3.5 \% \mathrm{CP}$ may suffer a net $\mathrm{N}$ loss because fecal $\mathrm{N}$ losses are $5.6 \mathrm{~g} \mathrm{~N} \mathrm{~kg}^{-1} \mathrm{DM}$ consumed (Mould and Robbins 1981).

Table 2 and Table 3 , respectively, describe the energy and $N$ content of bluebunch wheatgrass forage from each clipping treatment and the forage intake ( $\mathrm{kg} \mathrm{DM}$ day $\left.{ }^{-1}\right)$ required under each treatment to meet the maintenance and activity requirements of a free-ranging $200-\mathrm{kg}$ cow elk. On a diet composed entirely of bluebunch wheatgrass (control treatment), a cow elk must consume $8.5 \mathrm{~kg} \mathrm{DM} \mathrm{day}^{-1}$ or $4.3 \%$ of her body weight in forage to meet daily energy requirements for maintenance and activity during early November. The cow elk would have to consume $3.9 \%$ of body weight in bluebunch wheatgrass (control treatment) to meet her daily dietary $\mathrm{N}$ requirements. Even on a diet of bluebunch wheatgrass forage from the inflorescence emergence treatment, the treatment yielding the highest energy and $\mathrm{N}$ content, the cow elk must consume $3.5 \%$ and $2.7 \%$ of body weight in forage to meet her energy and dietary $\mathrm{N}$ requirements, respectively. The maximum DM intake rate for elk is assumed to be 2.0 to $2.5 \%$ of body weight (Hungerford 1952, Geis 1954), although recent research suggests elk may consume as much as $4.0 \%$ of body weight under extreme physiological and environmental conditions (Pers. Comm., John Cook, National Council of the Paper Industry for Air and Stream Improvement, 1 October 1996). Consequently, even with the improvements in forage quality produced by spring forage conditioning treatments, energy and $\mathrm{N}$ levels in bluebunch wheatgrass are likely to be submaintenance for wintering elk. In northeastern Oregon, elk conmonly winter on diets dominated by bluebunch wheatgrass and other forages of submaintenance-quality and may suffer substantial declines in body condition.

Although the previous discussion might suggest spring forage conditioning treatments are inconsequential to the nutritional status of wintering elk, when viewed from the perspective of minimizing weight loss and declines in body condition, forage quality improvements resulting from conditioning treatments may have pronounced effects. Based on data from Anderson et al. (1972), Robbins et al. (1974), McEwan (1975), and Simpson (1976), Hobbs et al. (1982) concluded $15 \%$ of body weight was a reasonable estimate for the fat reserves of an adult elk entering winter in average body condition. A $200-\mathrm{kg}$ cow elk in average condition would thus enter winter with $30 \mathrm{~kg}$ of fat available for catabolism. Catabolism of fat yields about $6 \mathrm{kcal} \mathrm{ME} / \mathrm{g}$ (Mautz 1978). If this cow elk wintered on a diet of $5 \mathrm{~kg} \mathrm{day}^{-1}$ of bluebunch wheat- 
grass from the control treatment (Table 2), she would have a daily dietary energy deficiency of $3785 \mathrm{kcal} \mathrm{ME}$. To compensate for this energy deficit she would have to catabolize $631 \mathrm{~g}$ of her fat reserves daily. At this rate of fat catabolism, assuming her energy requirements remained constant, her fat reserves would last for $\mathbf{4 8}$ days, after which she would have to catabolize protein to meet daily energy demands. On a diet of forage from the inflorescence emergence treatment, a $200-\mathrm{kg}$ cow elk would exhaust her fat reserves after 71 days or 3.3 weeks after an elk consuming forage from the control treatment. If this same elk consumed a diet of bluebunch wheatgrass from the mid-boot/whole-plant treatment, her fat reserves would last 70 days or 3.1 weeks longer than if she consumed a diet from the control treatment. The fat reserves of a $200-\mathrm{kg}$ elk consuming forage from the midboot/half-plant treatment would last 57 days or 1.3 weeks longer than on a diet of forage from the control treatment.

\section{Potential Improvements in Foraging Efficiency}

Several researchers have reported substantial increases in winter elk utilization of areas receiving facilitative livestock grazing (Anderson and Scherzinger 1975, Jourdonnais and Bedunah 1990, Frisina and Morin 1991). Notably, the phenological timing of these livestock grazing treatments was much less precise than the clipping treatments in the present study. The elk utilization responses observed in these earlier studies were probably related to a combination of interacting forage plant responses to the livestock grazing treatments. Reduction of standing litter accumulation (Anderson and Scherzinger 1975, Peek et al. 1979, Willms et al. 1980a, Jourdonnais 1985, Gordon 1988), reduction in the number of reproductive culms per plant (Ganskopp et al. 1992) and improvements in the nutritional quality of the forage probably all influenced the elk utilization responses in these studies. Livestock grazing treatments used to reduce standing litter and reproductive culms could be applied within a fairly wide phenological window and may substantially increase the accessibility of palatable forage to feeding ungulates (Willms et al. 1980a, Jourdonnais 1985).

In a forage conditioning study conducted on a bunchgrass/sagebrush rangeland in eastern Oregon, foragc samples from ungrazed plots and plots grazed by cattle in the spring were collected in the fall by clipping, i.e., total available forage, and by the use of esophageal-fistulated steers (Pers. Comm., Tim DelCurto, Eastern Oregon Agr. Res. Ctr., 13 September 1995). Although the clipping samples indicated a forage quality difference existed between the grazed and ungrazed plots on a total available forage basis, the fistula samples suggested the steers selectively grazed forage of similar quality from both the grazed and ungrazed plots and this selected forage was higher in quality than the total available forage in ungrazed plots. The steers may have selectively grazed the phenologically younger tillers from the current year's growth of individual plants and avoided reproductive culms and standing litter (Ganskopp et al. 1992). It is probably reasonable to assume elk wintering on bunchgrass-dominated rangelands would exhibit selective grazing behavior similar to the steers described above.

The energy expended while foraging represents a substantial portion of the daily energy budget of a wintering elk (Hobbs et al. 1982, Nelson and Leege 1982, Wickstrom et al. 1984). Consequently, foraging efficiency, i.e., energy expenditure/unit of nutrient ingested, may strongly influence the ability of an elk to meet its energy requirements during winter. As described above, it may be possible for elk to obtain forage of the same quality from conditioned and unconditioned forage by selective grazing. However, forage conditioning may not only enhance the overall nutritional quality of the forage by delaying plant phenology but may also increase the accessibility of phenologically younger portions of the plants by removing obstructing litter and unpalatable culms, decrease foraging time and distance traveled/unit of nutrient ingested, and decrease time exposed to predators and harsh environmental conditions while foraging. For elk that normally winter on a relatively low plane of nutrition, even small increases in foraging efficiency may be critically important.

\section{Literature Cited}

Anderson, A.E., D.E. Medin, and D.C. Bowden. 1972. Indices of carcass fat in a Colorado mule deer population. J. Wildl. Manage. 36:579-594.

Anderson, E.W. and R.J. Scherzinger. 1975. Improving quality of winter forage for elk by cattle grazing. J. Range Manage. 28:120-125.

Association of Official Analytical Chemists (AOAC). 1980. Official methods of analysis. 13th ed. Assoc. of Official Anal. Chem., Washington, D.C.

Blaisdell, J.P. and J.F. Pechanec. 1949. Effect of herbage removal at various dates on vigor of bluebunch wheatgrass and arrowleaf balsamroot. Ecol. 30:298-305.

Blaisdell, J.P., A.C. Wiese, and C.W. Hodgson. 1952. Variations in chemical composition of bluebunch wheatgrass, arrowleaf balsamroot, and associated range plants. J. Range Manage. 5:346 353.

Bryant, L.D. 1993. Quality of bluebunch wheatgrass (Agropyron spicatum) as a winter range forage for Rocky Mountain elk (Cervus elaphus nelsoni) in the Blue Mountains of Oregon. Ph.D. Diss., Oregon State Univ., Corvallis, Ore.

Busso, C.A. and J.H. Richards. 1995. Drought and clipping effects on tiller demography and growth of two tussock grasses in Utah. J. Arid Environ. 29:239-251.

Busso, C.A., R.J. Mueller, and J.H. Richards. 1989. Effects of drought and defoliation on bud viability in two caespitose grasses. Annals of Bot. 63:477-485.

Clark, P.E. 1996. Use of livestock to improve the quality of elk winter range forage in northeastern Oregon. Ph.D. Diss., Oregon State Univ., Corvallis, Ore.

Clark, P.E., W.C. Krueger, L.D. Bryant, and D.R. Thomas. 1998. Spring defoliation effects on bluebunch wheatgrass: II. Basal area. J. Range Manage. 51:526-530.

Daer, T. and E.E. Willard. 1981. Total nonstructural carbohydrate trends in bluebunch wheatgrass related to growth and phenology. $\mathrm{J}$. Range Manage. 34:377-379.

Dysterhuis, E.L. and C.T. High. 1985. Soil survey of Union County area, Oregon. USDA Soil Conserv. Serv. Washington, D.C.

Frisina, M.R. and F.G. Morin. 1991. Grazing private and public land to improve the Fleecer Elk Winter Range. Rangelands 13:291-294.

Ganskopp, D., R. Angell, and J. Rose. 1992. Response of cattle to cured reproductive stems in a caespitose grass. J. Range Manage. 45:401-404.

Geis, A.F. 1954. The food requirements and relative digestibility of a variety of winter diets fed to elk (Cervus ranadensis nelsoni) under controlled conditions. M.S. Thesis, Univ. Montana, Missoula, Mont.

Gordon, I.J. 1988. Facilitation of red deer grazing by cattle and its impact on red deer performance. J. Appl. Ecol. 25:1-9.

Hall, F.C. 1973. Plant communities of the Blue Mountains in eastern Oregon and southeastern Washington. USDA For. Serv. Area Guide R6 3-1. Washington, D.C.

Hobbs, N.T. 1979. Winter diet quality and nutritional status of elk in the upper montane zone, Colorado. Ph.D. Diss., Colorado State Univ., Fort Collins, Colo.

Hobbs, N.T., D.L. Baker, J.E. Ellis, D.M. Swift, and R.A. Green. 1982. Energy- and nitrogen-based estimates of elk winter-range carrying capacity. J. Wildl. Manage. 46:12-21. 
Hungerford, C. 1952. The food consumption and weight response of elk (Cervus canadensis nelsoni) under winter conditions. M.S. Thesis, Univ. Montana, Missoula, Mont.

Jourdonnais, C.S. 1985. Prescribed fire and cattle grazing influences on the vegetation and elk use of a rough fescue community. M.S. Thesis, Univ. Montana, Missoula, Mont.

Jourdonnais, C.S. and D.J. Bedunah. 1990. Prescribed fire and cattle grazing on an elk winter range in Montana. Wildl. Soc. Bull. 18:232-240.

Mautz, W.W. 1978. Nutrition and carrying capacity, p. 321-348. In: J.L. Schmidt and D.L. Gilbert (eds.), Big game of North America. Stackpole Books, Harrisburg, Penn.

McEwan, E.H. 1975. The adaptive significance of the growth patterns in cervids compared with other ungulate species. Zool. Zh. 54:1221-1232.

McIlvanie, S.K. 1942. Carbohydrate and nitrogen trends in bluebunch wheatgrass, Agropyron spicatum, with special reference to grazing influences. Plant Physiol. 17:540-547.

McLean, A. and Wikeem, S. 1985. Influence of season and intensity of defoliation on bluebunch wheatgrass survival and vigor in southern British Columbia. J. Range Manage. 38:21-26.

Moen, A.N. 1973. Wildlife ecology. W.H. Freeman and Co., San Francisco, Calif.

Montgomery, D.C. 1991. Design and analysis of experiments. 3rd ed. John Wiley \& Sons, New York, N.Y.

Mould, E.D. and C.T. Robbins. 1981. Nitrogen metabolism in elk. J. Wildl. Manage. 45:323-334.

Nelson, J.R. and T.A. Leege. 1982. Nutritional requirements and food habits, p. 323-367. In: J.W. Thomas, and D.E. Toweill (eds.) Elk of North America-ecology and management. Stackpole Books, Harrisburg, Penn.

Parker, K.L. and C.T. Robbins. 1985. Thermoregulation in ungulates, p. 161-182. In: R.J. Hudson and R.G. White (eds.), Bisenergetics of wild herbivores. CRC Press, Inc., Boca Raton, Fla.

Peek, J.M., R.A. Riggs, and J.L. Lauer. 1979. Evaluation of fall burning on bighorn sheep winter range. J. Range. Manage. 32:430-432.

Pitt, M.D. 1986. Assessment of spring defoliation to improve fall forage quality of bluebunch wheatgrass (Agropyron spicatum). J. Range Manage. 39:175-181.

Robbins, C.T. 1973. The biological basis for the determination of carrying capacity. Ph.D. Diss., Cornell Univ., Ithaca, N.Y.

Robbins, C.T., R.L. Prior, and J.T. Reid. 1974. Body composition of white-tailed deer. J. Anim. Sci. 38:871-876.

SAS. 1988. SAS/STAT user's guide. 6.03 ed. SAS Institute Inc. Cary, N.C.

Schommer, T.J. 1978. Seasonal in vitro digestion coefficients for energy and protein of central Washington elk diets. M.S. Thesis, Washington State Univ., Pullman, Wash.

Sheehy, D.P. 1987. Grazing relationships of elk, deer, and cattle on seasonal rangeland in northeastern Oregon. Ph.D. Diss., Oregon State Univ., Corvallis, Ore.

Sheehy, D.P. and M. Vavra. 1995. Managing wildlife in incomplete habitats. In: L. Starr (ed.) Nat. Resource News. 5:5-7. Blue Mountains Nat. Resources Inst., La Grande, Ore.

Sheehy, D.P. and M. Vavra. 1996. Ungulate foraging areas on seasonal rangeland in northeastern Oregon. J. Range Manage. 49:16-23.

Simpson, A.M. 1976. A study of the energy metabolism and seasonal cycles of captive red deer. Ph. D. Thesis, Univ. Aberdeen, Aberdeen, U.K.

Skovlin, J.M. and M. Vavra. 1979. Winter diets of elk and deer in the Blue Mountains, Oregon. USDA For. Serv. Res. Paper PNW-260. Washington, D.C.

Smith, G.E. 1971. Energy metabolism and metabolism of the volatile fatty acids, p. 543-562. In: D.C. Church (cd.), The digestive physiology of ruminants. vol. 2. Nutrition. O \& B Books, Inc., Corvallis, Ore.

Stoddart, L.A. 1946. Some physical and chemical responses of Agropyron spicatum to herbage removal at various seasons. Utah State Agr. Coll. Agr. Exp. Sta. Bull. 324. Logan, Ut.

Swift, D.M. 1983. A simulation model of energy and nitrogen balance for free-ranging ruminants. J. Wildl. Manage. 47:620-645.
Swift, D.M., J.E. Ellis, and N.T. Hobbs. 1981. Nitrogen and energy requirements of North American cervids in winter: a simulation study. Proc. Internat. Reindeer and Caribou Symp. 2:244-251.

Thompson, C.G., J.B. Holter, H.H. Hayes, H. Silver, and W.E. Urhan. 1973. Nutrition of white-tailed deer. I. Energy requirements of fawns. J. Wildl. Manage. 37:301-311.

Tilley, J.M.A. and R.A. Terry. 1963. A 2-stage technique for the in vitro digestion of forage crops. J. Brit. Grassl. Soc. 18:104-111.

Westenskow, K.J. 1991. Conditioning bunchgrass on elk winter range. M.S. Thesis, Oregon State Univ,, Corvallis, Ore.

Westenskow-Wall, K.J., W.C. Krueger, L.D. Bryant, and D.R. Thomas. 1994. Nutrient quality of bluebunch wheatgrass regrowth on elk winter range in relation to defoliation. J. Range Manage. 47:240-244.

Wickstrom, M.L., C.T. Robbins, T.A. Hanley, D.E. Spalinger, and S.M. Parish. 1984. Food intake and foraging energetics of elk and mule deer. J. Wildl. Manage. 48:1285-1301.

Willms, W., A.W. Bailey, and A. McLean. 1980a. Effect of burning or clipping Agropyron spicatum in the autumn on the spring foraging behaviour of mule deer and cattle. J. Appl. Ecology. 17:69-84.

Willms, W., A. McLean, and C. Kalnin. 1980b. Nutritive characteristics of grasses on spring range in south central British Columbia in relation to time, habitat and fall grazing. Can. J. Plant Sci. 60:131-137.

Wilson, A.M., G.A. Harris, and D.H. Gates. 1966. Cumulative effects of clipping on yield of bluebunch wheatgrass. J. Range Manage. 19:90-91 